\title{
Ilustración
}

\section{David de la Mano}

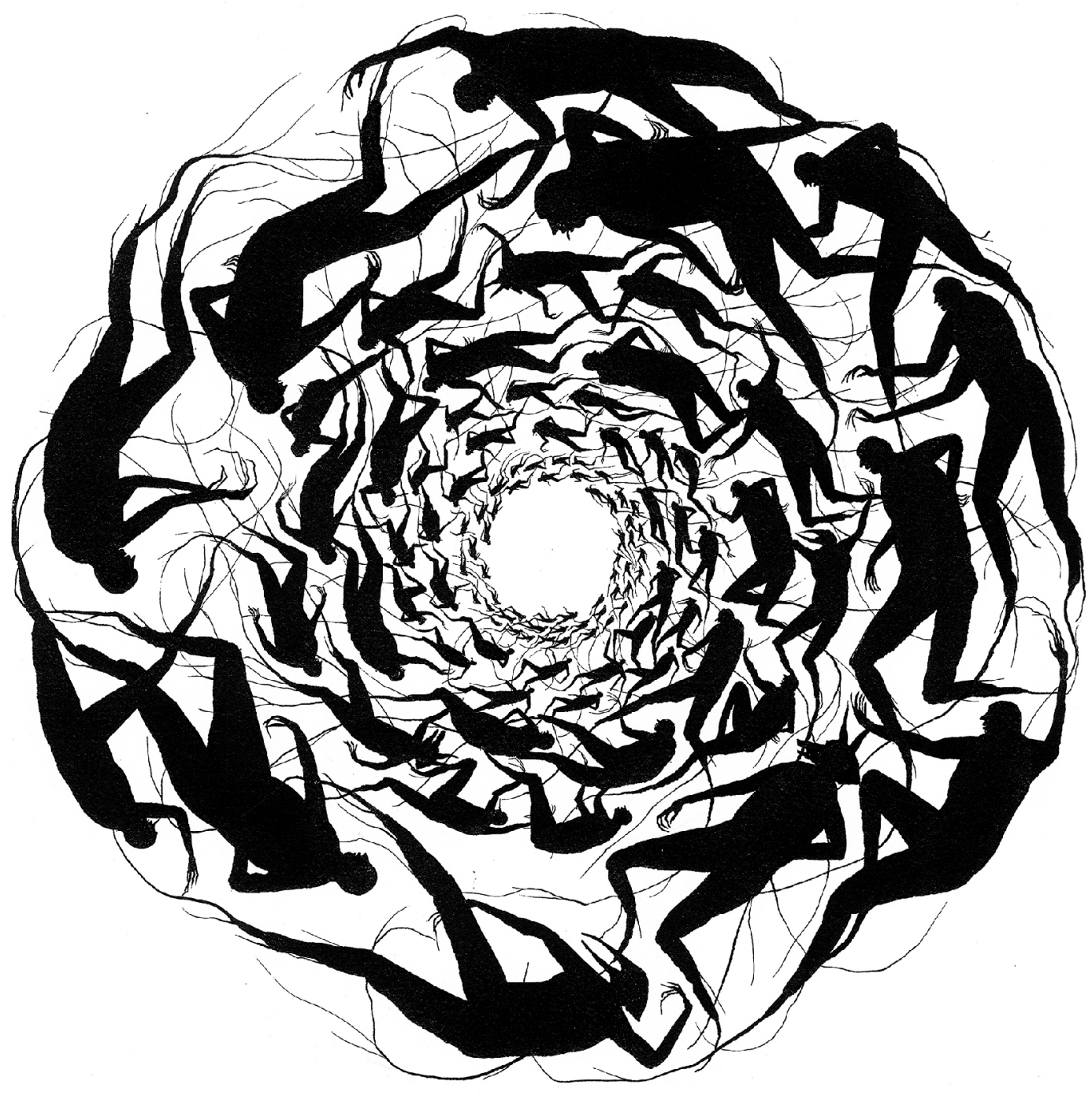

